RESEARCH ARTICLE

\title{
THE EFFECTS OF BIOCHAR AND COMPOST ON DIFFERENT CULTIVARS OF SHALLOTS (Allium ascalonicum L.) GROWTH AND NUTRIENT UPTAKE IN SANDY SOIL UNDER SALINE WATER
}

\author{
Rahayu*, Jauhari Syamsiyah, Vita Ratri Cahyani, and Siti Kharisma Fauziah \\ Department of Soil Science, Faculty of Agriculture, Universitas Sebelas Maret, JI. Ir. Sutami No.36A, \\ Jebres, Surakarta, Jawa Tengah 57126, Indonesia \\ Submitted: 2019-08-27 Accepted: 2019-12-11
}

\begin{abstract}
High salinity irrigation will cause nutrient uptake and shallot growth to deplete due to its sensitivity to salinity. This research aimed to investigate the effect of biochar and compost on shallot growth and nutrient uptake in sandy soil like Entisol when irrigated using salty water. This research carried out some pot experiments and put on the field using a completely randomized design. The first factor was based on the amendment with control of 20 tons ha $^{-1}$ of Biochar, 10 tons ha ${ }^{-1}$ of compost, and a mixture of 10 tons ha ${ }^{-1}$ biochar and 5 tons ha ${ }^{-1}$ of compost; the second factor was composed of 3 shallot cultivars (Brebes, Pemalang, and Purbalingga). Each pot was filled with $15 \mathrm{~kg}$ of soil; the pot $30 \mathrm{~cm}$ in diameter, incubated with saline water and irrigated by $2 \mathrm{dS} \mathrm{m}^{-1}$. The results show that irrigation with ground saline water causes Entisol to increase exchangable $\mathrm{Na}$, Ece and SAR, decrease exchangeable $\mathrm{Ca}$ and $\mathrm{Mg}$. The application of all treatments decreased SAR. The application of compost significantly increased $\mathrm{N}$ and $\mathrm{K}$ uptake but made soil $\mathrm{pH}, \mathrm{EC}$, and SAR to decrease while fresh weight and dry weight of bulb in Brebes cultivars increased. The combination of biochar with 5 tons ha ${ }^{-1}$ of compost produced the highest yield on plant height and number of tuber in Pemalang cultivars and had the largest tuber diameter in Purbalingga cultivars. There is an interaction between amendment and cultivar on plant height, fresh weight of tuber $(P<0.01)$, dry weight of tuber $(P<0.01)$.
\end{abstract}

Keywords: Biochar, Compost, Nutrient uptake, Salinity, Shallot

How to Cite: Rahayu, Syamsiyah, J. Cahyani, V. R., and Fauziah, S. K. (2019). The Effects of Biochar and Compost on Different Cultivars of Shallots (Allium ascalonicum L.) Growth and Nutrient Uptake in Sandy Soil Under Saline water. Sains Tanah Journal of Soil Science and Agroclimatology, 16(2): 216-228 (doi: 10.20961/stjssa.v16i2.34209)

Permalink/DOI: http://dx.doi.org/10.20961/stjssa.v16i2.34209

\section{INTRODUCTION}

Shallot is one of the most consumed commodities for seasoning in various dishes, fragrances, and enhancers of nutrients and medicines. The national consumption of

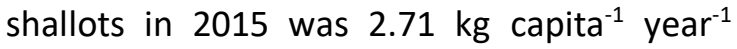
(Kementan, 2016).

\footnotetext{
* Corresponding Author:

Email: rahayu_pn@staff.uns.ac.id
}

According to Firmansyah, Liferdi, Khaririyatun, \& Yufdy (2015), Brebes district is the center of shallots production in Central Java. However, shallots production in 2014-2017 decreased from 12.15 tons ha- ${ }^{-1}$ to 9.39 tons $\mathrm{ha}^{-1}$ (BPS, 2018). One type of soil found in Brebes is Entisol or Alluvial and possibly affected by seawater intrusion. Commonly, alluvial soil has very low organic, nitrogen content and low nutrient. Even Brebes is production centers, but the current suitability classes are 
marginally suitable as the heaviest limiting factors are very high rainfall, and need improvement efforts to overcome this can be done by using suitable varieties (Rahayu, Mujiyo, \& Arini, 2018). Generally, the N-Total content of alluvial ranges from 0.10 of highway sewage deposits to 0.13 percent of reservoir deposits; thus nitrogen content in sediment soil is low (Haryanta, Thohiron, \& Gunawan, 2017). Seawater intrusion is also one of the causes of the decline in shallot production. Some of the problems often faced by shallot farmers in the northern sea area of Java, where seawater enters the irrigation canal and causes a high level of salinity in irrigation water (Saleh, 2010). Thus shallot production decreased in $2015-2016$ by $17.9 \%$ (BPS, 2018). Shallot is a plant that is sensitive to salinity stress. Salinity is a condition where soil contains a high concentration of dissolved salt but has much sodium $\left(\mathrm{Na}^{+}\right)$. Soil salinity can also occur due to the accumulation of salt in irrigation water which causes soil to be infertile. FAO (2006) estimates that areas with high salinity can have a negative effect of 20-25\% on irrigation water. The results of Koswara (2007) study showed that the weight of fresh bulb planted on saline land was only around 16.90-24.60 g plant ${ }^{-1}$, with lower crop compared in acid sulphate fields of 23.73 g plant $^{-1}$. Widawati and Suliasih (2017) study showed that bulb fresh weight in saline is $53.73 \mathrm{~g} \mathrm{pot}^{-1}$ was lower than in freshwater of $76.99 \mathrm{~g} \mathrm{pot}^{-1}$.

Irrigated rice fields along the north coast of Java experience problems of increasing salinity causing rice production to decline, especially in Indramayu (Erfandi \& Rachman, 2011). Agricultural land in Indonesia itself as a whole is experiencing salinity problems hovering $\quad 0.44$ million hectares (Purwaningrahayu \& Taufiq, 2018). The addition of saline land occurred in Aceh due to the entry of seawater into the mainland caused by a tsunami (Rachman, Subiksa, Erfandi, \&
Slavich, 2008). Salinity stress has negative effects on soil fertility and productivity and will seriously lead to environmental degradation in the future. In the years 2050, the extent of saline soils would continue to get higher as a result of declining water resources (Falkenmark, 2013). The management of saline land that has been carried out to improve the chemical, physical and biological properties of the soil in several ways, include the utilization of arbuscular mycorrhizal fungi and amelioration of deaminase-producing bacteria (Akhwan, Sulistyaningsih, \& Widada, 2012), water management using sub-surface drainage (Nasyirah, Kalsim, \& Saptomo, 2015), the application of gypsum and dolomite to wash $\mathrm{Na}$ ions exchanged with $\mathrm{CaSO}_{4 \cdot 2} \mathrm{H}_{2} \mathrm{O}$ ions (Sasongko \& Warsito, 2003), the use of Azolla pinnata ameliorant that can improve soil $\mathrm{pH}$ in salinity (Khoiriyyah, Setiawati, \& Suriadikusumah, 2017), the application of humic acid as much as $1 \mathrm{~g} \mathrm{~kg}^{-1}$ of soil to improve saline soil chemical properties that may increase the value of organic- $C$, available $P$ and N-total (Mindari, Aini, Kusuma, \& Syekhfani, 2014), and the use of fungal biofertilizers (Subowo, 2015). Biochar is a carbon-rich material that is burned with the intention to be used as an amendment to save carbon and to improve soil quality. Biochar is formed through the process of burning biomass or organic matter with little oxygen (pyrolysis) at temperatures of $250-500^{\circ} \mathrm{C}$ (Nurida, 2014). The mechanism of biochar in providing nutrients to plants is divided into three ways, namely: the ability of biochar in retaining nutrients, through the dynamics of microorganisms in the soil (Lehmann et al., 2003) cit (Lehmann \& Rondon, 2006), and the supply of nutrients directly from biochar (Mukherjee \& Zimmerman, 2013). Biochar, which is used as an amendment on saline-affected land, has a marked effect on reducing $\mathrm{Na}^{+}$concentration and balancing nutrient uptake (Akhtar et al, 
2015). In addition, biochar can also increase organic- $C$. The application of $5 \mathrm{~g}$ of biochar to saline soil can increase organic- $C$ by 1.2 units (Mindari et al., 2014). Biochar contains carboxyl groups that act as acids and amino groups as bases, which can be positively or negatively charged. In an alkaline environment, the amino will change into anion, and in an acidic environment, it turns into a cation.

Compost is an organic fertilizer derived from the results of weathering plant residues or organic waste, and can increase soil water holding capacity of sand, and can improve water movement between heavy soil textures rich in clay and silt. Compost is one of the appropriate amendments to be applied in saline soils. Compost can provide nutritional intake for plants and enhance plant growth. Rajiman, Yudono, Sulistyaningsih, and Hanudin (2008), reported that the application of organic matter in the form of manure and sugarcane compost applied to sandy soil increased the fresh weight of tuber by $116 \%$ and $128.7 \%$. Organic matter added as an amendment to saline soil can increase the availability of nitrogen, phosphorus, and potassium (Qadir, Ghafoor, \& Murtaza, 2001). On Ultisol soil, the supply of biochar and organic fertilizer has a significant effect on onion growth. There was an increase in plant height, leaf volume, tubular weight, tubular dry weight (Antonius, Sahputra, Nuraini, \& Dewi, 2018). In Ultisol soil, the application of biochar and organic fertilizer increased plant height, number of leaves, bulb fresh and dry weight (Antonius et al., 2018). Biochar also increases soil fertility through the physical properties of the soil so that plants can easily absorb nutrients (Gani, 2009). However, using biochar and compost as ameliorant in saline irrigation for shallot growth is limited; thus it is important to know the effect of biochar and compost on shallot growth and nutrient uptake in sandy soil when irrigated using saline water. The results proved to be useful for developing new management strategies meant to increase shallot production on salt-affected soil especially in the northern seaside of Java.

\section{MATERIALS AND METHODS}

This research used a completely randomized design experiment pot carried out from June to December 2017 in the experimental station of the Faculty of Agriculture, Universitas Sebelas Maret. The soil used is topsoil 0-30 cm Entisol from Plesungan, Gondangrejo, Karanganyar with latitude $7^{\circ} 31^{\prime}$ 54"S; $110^{\circ} 51^{\prime} 40^{\prime \prime} \mathrm{E}$, and summarized in Table 1. The Pot used is $30 \mathrm{~cm}$ in diameter, filled with soil as much as $15 \mathrm{~kg} \mathrm{pot}^{-1}$ and replicated 3 times. The soil was made saline by providing 2 $\mathrm{dS} \mathrm{m}^{-1}$ saline irrigation at field capacity and incubated for 2 weeks. Ameliorant was Biochar from wood charcoal and compost from livestock manure summarized in Table 2 . Biochar and compost were applied on the $2^{\text {nd }}$ week after incubation, with biochar amounting 20 tons ha- ${ }^{-1}$ (A1), compost of 10 tons ha-1 (A2) and mixed biochar and compost where biochar was 10 tons ha ${ }^{-1}$ while compost was 5 tons ha ${ }^{-1}$ (A3). In previous studies, maize yield did not increase with 20 tons ha ${ }^{-1}$ of biochar amendment in the first year but increased by 28-140\% in the following three years (Major, Rondon, Molina, Riha, \& Lehmann, 2010). The best dose for growing shallots was 10 tons ha-1 siam weed compost combined with a biocontrol agent and higher dosage of compost (Nugroho, Mildaryani, \& Dewi, 2019).

The used irrigation water was $2 \mathrm{dS} \mathrm{m}^{-1}$ according to the level of shallot sensitivity, obtained by dissolving $\mathrm{NaCl}$ in freshwater each with $1.28 \mathrm{gr} \mathrm{l}^{-1}$. Shallots planted as indicators were Brebes, Pemalang and Purbalingga cultivars. Shallots' growth will decrease watered by $2 \mathrm{dS} \mathrm{m}^{-1}$ for its threshold is $1.2 \mathrm{dS}$ $\mathrm{m}^{-1}$ (Grieve, Grattan, \& Maas, 2012). The top of the tuber was cut by $1 / 4$ part, planted with a 
distance of $10 \mathrm{~cm}$, where each pot has 3 tubers respectively. Fertilization was applied twice in the second week with urea $250 \mathrm{~kg} \mathrm{ha}^{-1}, \mathrm{Za} 180$ $\mathrm{kg} \mathrm{ha}^{-1}$, SP-36 $300 \mathrm{~kg} \mathrm{ha}^{-1}$, and $\mathrm{KCl} 200 \mathrm{~kg} \mathrm{ha}^{-1}$. SP-36 and $\mathrm{KCl}$, and the second were on the $4^{\text {th }}$ week of urea and $\mathrm{Za}$ as they approached the maximum vegetative period. Plants were maintained by watering using salty water as much as 1 liter pot ${ }^{-1}$ day $^{-1}$ equivalent to ETc.

The observed parameters were plant height after 2 weeks with 2 tubers pots ${ }^{-1}$ per sample then continued by harvesting after 10 weeks of cultivation. The measured parameters were the number of tubers, tubers diameter, fresh weight of shallot biomass after harvest, the open air-dry weight of shallot biomass after being dried during one week, dry weight tuber by using $70^{\circ} \mathrm{C}$ oven-dry shallot biomass. Plant $\mathrm{N}$ uptake was obtained by analyzing the $\mathrm{N}$ content in plant tissue using the Kjeldahl method (BPT, 2005); the phosphorus uptake and potassium in plants used wet ashing method of $\mathrm{HNO}_{3}$ and $\mathrm{HClO}_{4}$. The uptake analysis is carried out when the plant is at its maximum vegetative period. Compost and Biochar amendment analysis were $\mathrm{pH} \mathrm{H}_{2} \mathrm{O}$ ratio of $1: 2.5$, total $\mathrm{N}$ using Kjeldahl method, total $\mathrm{P}$ and total $\mathrm{K}$ by $\mathrm{HNO}_{3}$ and $\mathrm{HClO}_{4}$ extract methods, organic $\mathrm{C}$ with Walkley \& Black method. Soil analysis was measured first and the soil after incubation which was carried out including soil moisture analysis (gravimetric method), C-organic content (Walkley \& Black), cation exchange capacity (ammonium acetate extract), soil texture (pipette method), soil $\mathrm{pH}$ determination $(1: 2,5)$, soil paste electric conductivity (ECp) (1:5), total $N$ (Kjeldahl method), available $P$ (Olsen), $K$ available (flamefotometer) and exchanged bases (ammonium acetate extract). The value of ECp was measured and converted into soil extract electric conductivity (Ece), where Ece $=\operatorname{ECp}(1$ : 5) $x$ correction factor. Correction factor of soil texture index values, Alfisol 8.6 and Entisol 9 (Kargas et al., 2018). The data were analyzed using the $\mathrm{F}$ test with a $95 \%$ confidence level, followed by Duncan's Multiple Range Test.

Table 1. Characteristics of Entisols used in current study

\begin{tabular}{|c|c|c|}
\hline Soil Properties & Before Incubation* & After Incubation* \\
\hline $\mathrm{pH} \mathrm{H}_{2} \mathrm{O}$ & $7.192(N)$ & $7.286(N)$ \\
\hline Organic-C (\%) & $1.138(\mathrm{~L})$ & $1.175(\mathrm{~L})$ \\
\hline Total-N (\%) & $0.204(\mathrm{~L})$ & $0.167(L)$ \\
\hline Available-P (ppm) & $2.839(\mathrm{VL})$ & 4.480 (VL) \\
\hline Exchangeable-K $\left(\mathrm{me} 100 \mathrm{~g}^{-1}\right.$ ) & $0.672(\mathrm{M})$ & $1.210(\mathrm{H})$ \\
\hline Cation Exchange Capacity (me $100 \mathrm{~g}^{-1}$ ) & $18.043(\mathrm{M})$ & $18.312(\mathrm{M})$ \\
\hline Exchangeable- $\mathrm{Na}\left(\mathrm{me} 100 \mathrm{~g}^{-1}\right)$ & $0.123(\mathrm{~L})$ & $12.086(\mathrm{VH})$ \\
\hline Exchangeable-Ca (me $100 \mathrm{~g}^{-1}$ ) & $12.03(\mathrm{H})$ & $1.124(\mathrm{~L})$ \\
\hline Exchangeable-Mg $\left(\right.$ me $\left.100 \mathrm{~g}^{-1}\right)$ & $0.931(\mathrm{~L})$ & $0.349(\mathrm{~L})$ \\
\hline Base Saturation (\%) & $78.99(H)$ & $76.59(\mathrm{H})$ \\
\hline $\mathrm{EC}\left(\mathrm{mS} \mathrm{m}^{-1}\right)$ & $0.140(\mathrm{VL})$ & $260.76(\mathrm{M})$ \\
\hline Sodium Absorption Ratio (me $100 \mathrm{~g}^{-1}$ ) & $0.048(\mathrm{~L})$ & $12.105(\mathrm{VH})$ \\
\hline $\begin{array}{l}\text { Texture: Loam (Silt: } 39,3 \% \text {; Clay: } 17,6 \% \text {; } \\
\text { Sand: } 43,1 \% \text { ) }\end{array}$ & Loam & Loam \\
\hline
\end{tabular}


Table 2. Characteristics of biochar and compost

\begin{tabular}{lcc}
\hline Characteristics & Biochar & Compost \\
\hline $\mathrm{pH}$ & $9.9 \pm 0.32$ & $6.31 \pm 0.17$ \\
Organic-C (\%) & $59.202 \pm 5.44$ & $40.842 \pm 4.12$ \\
Total-N (\%) & $2.253 \pm 0.09$ & $2.649 \pm 0.72$ \\
Total-P (\%) & $0.387 \pm 0.18$ & $0.383 \pm 0.12$ \\
Total-K (\%) & $0.02 \pm 0.005$ & $0.037 \pm 0.006$ \\
C/N Ratio & $26.277 \pm 0.98$ & $15.417 \pm 0.67$ \\
\hline
\end{tabular}

Table 3. $\mathrm{pH}, \mathrm{EC}$, and SAR in the soil-applied with the amendment

\begin{tabular}{|c|c|c|c|}
\hline Soil Amendment & pH & $\mathrm{EC}\left(\mathrm{dS} \mathrm{m}^{-1}\right)$ & SAR $\left(\mathrm{cmol} \mathrm{kg}^{-1}\right)$ \\
\hline Control & $6.75 b$ & $1.81 a$ & $0.59 b$ \\
\hline Biochar 20 tons ha ${ }^{-1}$ & $6.75 b$ & $2.31 b$ & $0.27 a$ \\
\hline Compost 10 tons ha ${ }^{-1}$ & $6.29 a$ & $1.75 a$ & $0.31 a$ \\
\hline $\begin{array}{l}\text { Biochar } 10 \text { tons ha }{ }^{-1}+ \\
\text { Compost } 5 \text { tons ha-1 }\end{array}$ & $6.68 b$ & $1.80 a$ & $0.29 a$ \\
\hline
\end{tabular}

Remark: the mean in column followed by the same letters in each column are not significantly different according to DMRT at $5 \%$ level.

\section{RESULTS}

Irrigation with ground saline water causes entisol to increase exchangeable $\mathrm{Na}$ from 0.12 to $12.09 \mathrm{cmol} \mathrm{kg}^{-1}$, increase in Ece from $0.140 \mu$ mhos $\mathrm{cm}^{-1}$ to $260,76 \mu$ mhos $\mathrm{cm}^{-1}$, and increase in SAR from 0.048 to 12.10 unit during incubation prior to cultivation. An increase was also observed in available $P$ content and available K. After incubation, another change was noticed which include a decrease in exchangeable $\mathrm{Ca}$ from 12.03 to $1.124 \mathrm{cmol} \mathrm{kg}^{-1}$ and $\mathrm{Mg}$ from 0.931 to 0.349 cmol kg (Table 1). 10 tons ha-1 of compost significantly reduces $\mathrm{pH}$. The application of all treatments significantly decreased SAR. However, the application of biochar of 20 tons ha $^{-1}$ significantly increased EC (Table 3). In general, amongst the three varieties, control has the lowest nutrient uptake. In Brebes and Purbalingga cultivars, the $A 2$ and $A 3$ treatments significantly increased $\mathrm{N}$ uptake while A1 treatment did not in both cultivars. In Pemalang cultivars, all treatments increased $\mathrm{N}$ uptake with the highest uptake in the treatment of 10 tons ha $^{-1}$ of compost. From these results, it appears that the increase in $\mathrm{N}$ uptake is influenced by compost rather than by biochar (Table 4). A biochar of 20 tons ha ${ }^{-1}$ can reduce SAR level by as much as $45 \%$ from 0.59 $\mathrm{cmol} \mathrm{kg}^{-1}$ to $0.27 \mathrm{cmol} \mathrm{kg}^{-1}$, but the results are not significantly different $(p>0.05)$ compared to compost of 10 tons ha-1 (A2) or a combination of biochar of 10 tons ha $^{-1}$ with compost 5 tons ha $^{-1}$ (A3). The amendment interaction and cultivars were significant ( $p$ $<0.01$ ) on $\mathrm{N}$ and $\mathrm{P}$ uptake, but the cultivar treatment was not significant. In Table 4 it appears that all treatments did not influence $P$ uptake; however, compost application of 10 tons $\mathrm{ha}^{-1}$ in Pemalang cultivar had the highest nitrogen uptake. 
Rahayu et al. / SAINS TANAH - Journal of Soil Science and Agroclimatology, 16(2), 2019, 221

Table 4. Nutrient uptake of cultivars with the amendment.

\begin{tabular}{|c|c|c|c|c|}
\hline \multirow[b]{2}{*}{ Cultivar } & \multirow[b]{2}{*}{ Amendment } & \multicolumn{3}{|c|}{ Nutrient Uptake } \\
\hline & & $\begin{array}{c}\mathrm{N} \\
\left.\text { (mg plant }^{-1}\right)\end{array}$ & $\begin{array}{c}P \\
\left(\text { mg plant }^{-1}\right)\end{array}$ & $\begin{array}{c}\mathrm{K} \\
\left.\text { (mg plant }^{-1}\right)\end{array}$ \\
\hline \multirow{4}{*}{ Brebes } & Control & $10.98 \mathrm{ef}$ & $0.14 \mathrm{~b}$ & $14.78 \mathrm{e}$ \\
\hline & Biochar 20 tons ha ${ }^{-1}$ & 21.31 ef & $0.09 \mathrm{~b}$ & $21.14 \mathrm{de}$ \\
\hline & Compost 10 tons ha ${ }^{-1}$ & 58.02 cde & $0.11 \mathrm{~b}$ & 37.38 cde \\
\hline & $\begin{array}{l}\text { Biochar } 10 \text { tons ha }{ }^{-1}+\text { Compost } 5 \\
\text { tons ha }{ }^{-1}\end{array}$ & $101.23 \mathrm{bc}$ & $0.10 \mathrm{~b}$ & 45.08 bcde \\
\hline \multirow{4}{*}{ Pemalang } & Control & 12.86 ef & $0.04 \mathrm{~b}$ & $12.97 \mathrm{e}$ \\
\hline & Biochar 20 tons ha ${ }^{-1}$ & $51.31 \mathrm{def}$ & $0.29 \mathrm{~b}$ & $96.16 \mathrm{ab}$ \\
\hline & Compost 10 tons ha ${ }^{-1}$ & $179.24 \mathrm{a}$ & $0.32 b$ & $136.17 \mathrm{a}$ \\
\hline & $\begin{array}{l}\text { Biochar } 10 \text { tons ha }^{-1}+\text { Compost } 5 \\
\text { tons ha- }{ }^{-1}\end{array}$ & $96.53 \mathrm{bcd}$ & $1.26 \mathrm{a}$ & $78.45 \mathrm{bc}$ \\
\hline \multirow{4}{*}{ Purbalingga } & Control & $10.98 \mathrm{f}$ & $0.03 \mathrm{~b}$ & $10.40 \mathrm{e}$ \\
\hline & Biochar 20 tons ha ${ }^{-1}$ & 44.34 ef & $0.13 b$ & $37.83 \mathrm{cde}$ \\
\hline & Compost 10 tons ha ${ }^{-1}$ & 59.80 cde & $0.21 \mathrm{~b}$ & 57.85 bcde \\
\hline & $\begin{array}{l}\text { Biochar } 10 \text { tons ha }{ }^{-1}+\text { Compost } 5 \\
\text { tons ha }{ }^{-1}\end{array}$ & $119.64 \mathrm{~b}$ & $0.44 b$ & $74.25 \mathrm{bcd}$ \\
\hline
\end{tabular}

Remark: the mean in column followed by the same letters on the table are not significantly different at $5 \%$ level

Table 5. The effect of amendment with cultivars on plant height

\begin{tabular}{llll}
\hline \multirow{2}{*}{ Amendment } & \multicolumn{3}{c}{$\begin{array}{c}\text { Plant height } \\
\text { (cm) }\end{array}$} \\
\cline { 2 - 4 } & \multicolumn{3}{c}{ Cultivars } \\
\cline { 2 - 4 } & \multicolumn{1}{c}{ Brebes } & \multicolumn{3}{c}{ Pemalang } \\
\hline Control & 20.67 abcd & 19.93 abcd & $22.17 \mathrm{abc}$ \\
Biochar 20 tons ha $^{-1}$ (A1) & $14.47 \mathrm{~d}$ & $20.43 \mathrm{abcd}$ & $18.33 \mathrm{bcd}$ \\
Compost 10 tons ha $^{-1}$ (A2) & $18.33 \mathrm{bcd}$ & $24.67 \mathrm{abc}$ & $25.67 \mathrm{ab}$ \\
Biochar 10 tons ha ${ }^{-1}+$ compost & $17.50 \mathrm{~cd}$ & $25.83 \mathrm{a}$ & $22.00 \mathrm{abc}$ \\
5 tons ha & & \\
\hline Remark: (A3) & & & \\
\hline
\end{tabular}

Table 6. The effect of amendment with cultivars on number and diameter of tuber

\begin{tabular}{|c|c|c|c|c|c|c|}
\hline \multirow{3}{*}{ Amendment } & \multicolumn{6}{|c|}{ Cultivars } \\
\hline & \multicolumn{2}{|c|}{ Brebes } & \multicolumn{2}{|c|}{ Pemalang } & \multicolumn{2}{|c|}{ Purbalingga } \\
\hline & $\begin{array}{l}\text { Tuber } \\
\text { Number }\end{array}$ & $\begin{array}{c}\text { Tuber } \\
\text { Diameter }\end{array}$ & $\begin{array}{l}\text { Tuber } \\
\text { Number }\end{array}$ & $\begin{array}{c}\text { Tuber } \\
\text { Diameter }\end{array}$ & $\begin{array}{c}\text { Tuber } \\
\text { Number }\end{array}$ & $\begin{array}{c}\text { Tuber } \\
\text { Diameter }\end{array}$ \\
\hline Control & $3.33 \mathrm{~d}$ & $0.65 \mathrm{c}$ & $3.00 \mathrm{~d}$ & $0.61 \mathrm{c} 3$ & $3.33 \mathrm{~d}$ & $0.74 \mathrm{c}$ \\
\hline Biochar 20 tons ha-1 $(\mathrm{A} 1)$ & $4.33 \mathrm{bcd}$ & $1.42 \mathrm{~b}$ & $7.33 \mathrm{ab}$ & $1.53 \mathrm{~b} \in$ & $6.00 \mathrm{abcd}$ & $1.73 \mathrm{~b}$ \\
\hline Compost 10 tons ha-1 $(A 2)$ & $7.67 \mathrm{ab}$ & $1.68 \mathrm{~b}$ & $5.67 \mathrm{abcd}$ & $1.58 \mathrm{~b} 7$ & $7.00 \mathrm{abc}$ & $1.39 \mathrm{~b}$ \\
\hline $\begin{array}{l}\text { Biochar } 10 \text { tons ha- }{ }^{-1} \\
\text { compost } 5 \text { tons ha- }{ }^{-1}(\mathrm{~A} 3)\end{array}$ & $6.00 \mathrm{abcd}$ & $1.68 \mathrm{~b}$ & $8.33 \mathrm{a}$ & $1.64 \mathrm{~b} 3$ & $3.67 \mathrm{~cd}$ & $2.25 \mathrm{a}$ \\
\hline
\end{tabular}


Table 7. The effect of amendment with cultivars on wet weight of tuber

\begin{tabular}{|c|c|c|c|}
\hline \multirow{2}{*}{ Amendment } & \multicolumn{3}{|c|}{ Cultivars } \\
\hline & Brebes & Pemalang & Purbalingga \\
\hline Control & $6.87 \mathrm{e}$ & $7.20 \mathrm{e}$ & $6.83 \mathrm{e}$ \\
\hline Biochar 20 tons ha-1 (A1) & $12.00 \mathrm{cde}$ & $18.33 \mathrm{abc}$ & $9.24 \mathrm{de}$ \\
\hline Compost 10 tons ha $\mathrm{ha}^{-1}(\mathrm{~A} 2)$ & $22.30 \mathrm{a}$ & $16.37 \mathrm{abcd}$ & $20.75 a b$ \\
\hline $\begin{array}{l}\text { Biochar } 10 \text { tons ha- }{ }^{-1}+ \\
\text { compost } 5 \text { tons ha-1 (A3) }\end{array}$ & $17.60 \mathrm{abc}$ & 10.73 cde & 13.77 bcde \\
\hline
\end{tabular}

Table 8. The effect of amendment with cultivars on the dry weight of tuber

\begin{tabular}{llcc}
\hline \multirow{2}{*}{ Amendment } & \multicolumn{3}{c}{ Cultivars } \\
\cline { 2 - 4 } & Brebes & Pemalang & Purbalingga \\
\hline Control & $3.70 \mathrm{c}$ & $4.36 \mathrm{bc}$ & $5.40 \mathrm{bc}$ \\
Biochar 20 tons ha ${ }^{-1}$ (A1) & $8.17 \mathrm{abc}$ & $16.17 \mathrm{ab}$ & $11.67 \mathrm{abc}$ \\
Compost 10 tons ha $^{-1}$ (A2) & $20.03 \mathrm{a}$ & $14.60 \mathrm{abc}$ & $17.80 \mathrm{a}$ \\
Biochar 10 tons ha & -1 \\
compost 5 tons ha ${ }^{-1}$ (A3) & $15.73 \mathrm{abc}$ & $8.23 \mathrm{abc}$ & $12.80 \mathrm{abc}$ \\
\hline
\end{tabular}

Remark: the mean followed by the same letters on the table are not significantly different at $5 \%$ level

In general, nutrient uptake at control is the lowest in all three varieties. In Brebes and Purbalingga cultivars, the $\mathrm{A} 2$ and $\mathrm{A} 3$ treatments significantly increased $\mathrm{K}$ uptake while A1 did not in both cultivars. In Pemalang cultivars, all treatments increased the $\mathrm{K}$ uptake with the highest uptake in treatment $A 2$, ie 10 tons ha ${ }^{-1}$ of compost. From these results, it can be seen that the increase in $\mathrm{K}$ uptake was influenced by compost and also biochar (Table 4). Nitrogen and $K$ uptake were significantly negatively correlated $(p<0.05)$ to soil SAR ( $r=-$ 0.375 and -0.3341 ). Compost of 10 tons ha ${ }^{-1}$ had the highest phosphorus uptake and had a significant effect $(p<0.01)$ on $K$ uptake. The application of 10 tons of compost ha- ${ }^{-1}$ increased $K$ uptake in all three shallots cultivars. There were interactions between amendment and cultivar for plant nutrient uptake $(P<0.01)$. From Table 5 , it appears that the treatment did not have a significant effect on plant height in cultivars, but the difference was seen in the application of a mixture of biochar and compost that increased plant height in Pemalang cultivars compared to the application of biochar in Brebes cultivars.
Amendment interactions with cultivars had a significant effect $(p<0.05)$ on plant height, shallot tuber diameter, fresh and dry weight of tuber. Pemalang cultivars showed the highest plant whereas Brebes cultivars had the lowest plant height in various amendments. Plant height was positively correlated ( $p>0.05$ ) to $N$ uptake $(r=0.291)$. Amendments significantly increased the number of tubers in the three different cultivars. From Table 6, it appears that compost increases the number of tubers in the onion cultivars of Brebes and Purbalingga, while in Pemalang cultivars the application of biochar increases the number of onion tubers. All treatments, either compost, biochar or mixed compositions of biochar and compost significantly increased the tuber diameter in all cultivars, and there was no difference in the effect of these different treatments on the tuber diameter in the Brebes and Pemalang cultivars. Giving a mixture of biochar and compost significantly increases the diameter of the tubers in Purbalingga onions compared to the provision of compost or biochar separately. There is an interaction between amendment and cultivar 
on plant height, tuber diameter and weight $(\mathrm{P}<$ 0.01). 10 tons ha $^{-1}$ of biochar plus 5 tons ha- ${ }^{-1}$ of compost in Pemalang cultivars had the highest bulb number with 8.33 , but it was not significantly different from the number of bulbs in the three cultivars on compost of 10 tons ha ${ }^{-1}$ (Table 6). The combination of 10 tons $\mathrm{ha}^{-1}$ of biochar and 5 tons ha- $\mathrm{h}^{-1}$ of compost in Purbalingga cultivars showed the biggest bulb diameter of $2.25 \mathrm{~cm}$. Table 7 showed that compos increase the weight of three cultivar shallot tuber. Biochar increases the tuber weight of Pemalang, There was no interaction between biochar and compos in tuber weight.

\section{DISCUSSION}

Increasing the dry weight of shallots can be improved by administering NPK fertilizers (Istina, 2016). On the other hand, soil $\mathrm{N}$ mineralization reduced by excessive absorption of $\mathrm{Na}$ (Sembiring, Gani, \& Iskandar, 2008). According to Wigati, Syukur, and Bambang (2016), the concentration and $P$ uptake in plant tissues increased by giving compost fertilizer of 20 tons ha ${ }^{-1}$. Compost increases $\mathrm{K}$ absorption in all three shallots cultivars in saline exchangeable. The application of compost increases shallots $\mathrm{K}$ uptake (Wahyudi, 2013). However, high $\mathrm{NaCl}$ absorption would reduce K uptake (Parida \& Das, 2004). Hansen, Blackmer, Mallarino, \& Wuebker (2004) reported the high exchangeable $\mathrm{Na}$ content in the soil which would inhibit the absorption of nutrients $\mathrm{K}, \mathrm{Ca}$ and $\mathrm{Mg}$ from the soil, thereby suppressing plant growth. The provision of cow manure plus straw mulch can help increase plant height and the number of shallots (Mayun, 2007). Giving amendments made from organic may increase the height of shallot in saline conditioned soil. Decomposed organic matters will produce a number of proteins and amino acids which break down into ammonium and nitrate (Hasanudin, 2003). Nitrogen is a composition of amino acids in the formation of proteins to stimulate vegetative growth (Putra, Wahyudi, \& Hasanah, 2015). Amendments significantly increased the number of shallots bulbs and bulb diameter in the three different cultivars. Zaki (2016) states that one of the advantages of compost is that it can be used as a source of nutrition ( $\mathrm{P}$ and $\mathrm{K}$ ) whose value increases after harvest. Soil amendments derived from cow dung increase bulb weight on shallots (Mayun, 2007). The fresh bulb weight of shallot was significantly and positively correlated with $\mathrm{K}$ uptake. According to Simanjuntak et al. (2013), K elements function in starch formation and translocation of photosynthetic results to accelerate bulb growth. More $\mathrm{K}$ is needed in bulbs since $\mathrm{K}$ functions as an enzyme activator that has a direct effect on metabolic processes (Anisyah et al, 2014). Organic matters increase the number of shallot tubers. Potassium can bind water in plant tissue hastening the process of photosynthesis which will later affect the formation of larger tubers, and increase the dry weight of shallot tubers (Anisyah et al., 2014). However, fresh shallot tubers can experience shrinkage of around $15-19 \%$ of the total weight (Djali \& Putri, 2013)

C-organic in each soil, both before and after incubation is classified as low (Table 1). The low organic matter in the soil can be caused by intensive soil tillage (Munir, 1996). The difference between soil before and after incubation of saline water is the exchange cations, EC and SAR. Soil is classified as saline soil when it has electrical conductivity (EC) over

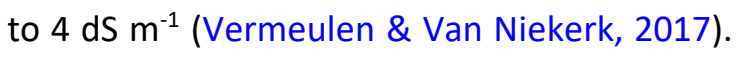
Sasongko and Warsito (2003) reported that a large amount of dissolved and exchangeable $\mathrm{Na}$ salt concentrations showed that the soil was exposed to salinity. The $\mathrm{C} / \mathrm{N}$ ratio of biochar still exceeds the specified threshold (Table 3). According to Permentan (2011), the $\mathrm{C} / \mathrm{N}$ ratio of soil amendment can be applied to 
the soil when ranges are between 15-25. According to regulation, it is also considered that the content of $\mathrm{N}, \mathrm{P}, \mathrm{K}$ of amendment must be less than $6 \%$ (Permentan, 2011). The addition of amendments in the form of biochar does not have a significant effect on the $\mathrm{pH}$ of Entisol (Table 3). This result is similar to Gaskin et al. (2010) asserting that biochar on neutral soils has no significant effect on $\mathrm{pH}$ values. 10 tons $\mathrm{ha}^{-1}$ of compost (A2) has a significant effect in reducing the $\mathrm{pH}$ of Entisol. According to Mahdy (2011), compost derived from plant residues can reduce $\mathrm{pH}$ values in salineconditioned soils. Compost can reduce EC when applied beyond 6 tons ha ${ }^{-1}$ (Mulyono, 2000). The addition of organic matter to the soil plays an important role in microbial activity and enzymatic activities (Tejada, Garcia, Gonzalez, \& Hernandez, 2006). The application of all treatments significantly decreased SAR. However, the application of 20 tons ha ${ }^{-1}$ of biochar significantly increased soil EC (Table 3). The high value of EC will greatly affect plant growth. Ma'ruf (2016) reported that salinity can reduce plant productivity and nutrient uptake. The application of 20 tons $\mathrm{ha}^{-1}$ of biochar can reduce SAR of Entisol. High doses of biochar can absorb the ions in saline water which will consequently increase the soil EC (Soinne, Hovi, Tammeorg, \& Turtola, 2014). Thomas et al. (2013) claimed that high EC value was observed when 50 tons ha ${ }^{-1}$ of biochar was applied. Chaganti (2014) revealed that salt washing $(\mathrm{NaCl})$ can be done by adding organic materials such as compost and biochar which will increase the carbon content in the soil and boost microorganisms' activity. Biochar and green compost may reduce the soil SAR by replacing the $\mathrm{Na}^{+}$with $\mathrm{Ca}^{2+}$ and $\mathrm{Mg}^{2+}$ ions (Chaganti, 2014). Compost can help increase the availability of $\mathrm{N}$ which affects increasing $\mathrm{N}$ uptake in saline condition. Orman (2012) stated that organic fertilizer added to tomato plantations in saline soil significantly increased the nitrogen content. Nitrates and ammonium uptake in some plants are reduced due to the treatment of $\mathrm{NaCl}$ and the inclusion of salt levels in the soil (Parida \& Das, 2004).

\section{CONCLUSIONS}

Irrigation with ground saline water causes Entisol to increase exchangeable $\mathrm{Na}$, Ece and SAR, decrease exchangeable $\mathrm{Ca}$ and $\mathrm{Mg}$. The application of biochar and compost decreased SAR. The application of compost and biochar + compost significantly increased $\mathrm{N}$ and $\mathrm{K}$ uptake in Brebes and Purbalingga cultivars. The increase in $\mathrm{N}$ uptake is influenced by compost rather than by biochar, while the increase in $K$ uptake is influenced by both compost and biochar. Pemalang cultivars had the highest plant height while Brebes cultivars had the lowest plant height in various amendments. Amendments increased the number and bulb diameter. Compost increases the number of the bulb in the onion cultivars of Brebes and Purbalingga, while in Pemalang cultivars the application of biochar increases the amount of bulb. A combination of biochar and compost showed the highest bulb number in Pemalang, cultivars and bigger bulb diameter of Purbalingga cultivar.

\section{REFERENCES}

Akhtar, S. S., Andersen, M. N., \& Liu, F. (2015). Residual effects of biochar on improving growth, physiology, and yield of wheat under salt stress. Agricultural Water Management, 158, 61-68. https://doi.org/10.1016/j.agwat.2015.04 .010

Akhwan, I. A. S., Sulistyaningsih, E., \& Widada, J. (2012). Peran JMA dan Bakteri Penghasil ACC Deaminase Terhadap Pertumbuhan dan Hasil Bawang Merah Pada Cekaman Salinitas. Vegetalika, 1(2), 139-152.

Anisyah, F., Sipayung, R., \& Hanum, C. (2014). Pertumbuhan Dan Produksi Bawang Merah Dengan Pemberian Berbagai 
Pupuk Organik. Jurnal Online Agroekoteknologi, 2(2), 482-496. https://doi.org/10.32734/jaet.v2i2.7051

Antonius, S., Sahputra, R. D., Nuraini, Y., \& Dewi, T. K. (2018). Manfaat Pupuk Organik Hayati, Kompos dan Biochar pada Pertumbuhan Bawang Merah dan Pengaruhnya terhadap Biokimia Tanah Pada Percobaan Pot Menggunakan Tanah Ultisol. Jurnal Biologi Indonesia, 14(2), 243-250.

BPS. (2018). Luas Penen, Produksi Dan Ratarata Produksi Bawang Merah Di Kabupaten Brebes 2012 -2017. Retrieved June 10, 2019, from https://brebeskab.bps.go.id/dynamictable /2018/12/31/62/luas-penen-produksidan-rata-rata-produksi-bawang-merahdi-kabupaten-brebes-2012--2017.html

BPT. (2005). Petunjuk Teknis: Analisis Kimia Tanah, Tanaman, Air, dan Pupuk. Bogor, Indonesia: Balai Penelitian Tanah.

BPT. (2009). Petunjuk Teknis 2: Analisis Kimia Tanah, Tanaman, Air, dan Pupuk. Bogor, Indonesia: Balai Penelitian Tanah.

Chaganti, V. S. N. (2014). Evaluating the Potential of Biochars and Composts as Organic Amendments to Remediate a Saline-Sodic Soil Leached with Reclaimed Water. University of California.

Djali, M., \& Putri, S. H. (2013). The Characteristic Change of Shallot (Allium ascalonicum L.) During Curing Process. International Journal on Advanced Science, Engineering and Information Technology, 3(2), 61-65. https://doi.org/10.18517/ijaseit.3.2.303

Erfandi, D., \& Rachman, A. (2011). Identification of Soil Salinity Due to Seawater Intrusion on Rice Field in the Northern Coast of Indramayu, West Java. Journal of Tropical Soils, 16(2), 115-121. https://doi.org/10.5400/jts.2011.v16i2.1 15-121

Falkenmark, M. (2013). Growing water scarcity in agriculture: future challenge to global water security. Philosophical Transactions of the Royal Society A: Mathematical, Physical and Engineering Sciences, 371(2002), 20120410. https://doi.org/10.1098/rsta.2012.0410
FAO. (2006). Water desalination for agricultural applications. (J. M. Beltrán \& S. Koo-Oshima, Eds.). Rome, Italy: FAO.

Firmansyah, I., Liferdi, Khaririyatun, N., \& Yufdy, M. P. (2015). Pertumbuhan dan Hasil Bawang Merah dengan Aplikasi Pupuk Organik dan Pupuk Hayati pada Tanah Alluvial. Jurnal Hortikultura, 25(2), 133-141.

Gani, A. (2009). Potensi Arang Hayati "Biochar" sebagai Komponen Teknologi Perbaikan Produktivitas Lahan Pertanian. Iptek Tanaman Pangan, 4(1), 33-48.

Gaskin, J. W., Speir, R. A., Harris, K., Das, K. C., Lee, R. D., Morris, L. A., \& Fisher, D. S. (2010). Effect of Peanut Hull and Pine Chip Biochar on Soil Nutrients, Corn Nutrient Status, and Yield. Agronomy Journal, 102(2), 623. https://doi.org/10.2134/agronj2009.0083

Grieve, C. M., Grattan, S. R., \& Maas, E. V. (2012). Plant Salt Tolerance. In W. W. Wallender \& K. K. Tanji (Eds.), Agricultural Salinity Assessment and Management (2nd ed., pp. 405-459). Reston, VA: American Society of Civil Engineers. https://doi.org/10.1061/9780784411698 .ch13

Hansen, D. J., Blackmer, A. M., Mallarino, A. P., \& Wuebker, M. A. (2004). PerformanceBased Evaluations of Guidelines for Nitrogen Fertilizer Application after Animal Manure. Agronomy Journal, 96(1), 34.

https://doi.org/10.2134/agronj2004.0034 Haryanta, D., Thohiron, M., \& Gunawan, B. (2017). Kajian Tanah Endapan Perairan Sebagai Media Tanam Pertanian Kota. Journal of Research and Technology, 3(2), 1-10.

Hasanudin. (2003). Peningkatan Ketersediaan Dan Serapan N Dan P Serta Hasil Tanaman Jagung Melalui Inokulasli Mikoriza, Azotobakter Dan Bahan Organik Pada Ultisol. Jurnal Ilmu-Ilmu Pertanian Indonesia, 5(2), 83-89.

Istina, I. N. (2016). Peningkatan Produksi Bawang Merah Melalui Teknik Pemupukan NPK. Jurnal Agro, 3(1), 3642. https://doi.org/10.15575/810

Kargas, G., Chatzigiakoumis, I., Kollias, A., 
Spiliotis, D., Massas, I., \& Kerkides, P. (2018). Soil Salinity Assessment Using Saturated Paste and Mass Soil:Water 1:1 and 1:5 Ratios Extracts. Water, 10, 1589. https://doi.org/10.3390/w10111589

Kementan. (2016). Outlook Komoditas Pertanian Sub Sektor Hortikultura Bawang Merah. (Suwandi, L. Nuryati, B. Warianto, \& V. J. Siagian, Eds.). Jakarta: Pusat Data dan Sistem Informasi Pertanian, Kementerian Pertanian.

Khoiriyyah, L., Setiawati, M. R., \& Suriadikusumah, A. (2017). Pengaruh $\mathrm{NaCl}$ dan Amelioran Organik Azolla pinnata Terhadap N-Total, pH Tanah, Serta Bobot Kering Tanaman Padi (Oryza sativa L.) Pada Inceptisols Jatinangor. Jurnal Agroekoteknologi, 9(2). https://doi.org/10.33512/j.agrtek.v9i2

Koswara, E. (2007). Teknik pengujian daya hasil beberapa varietas bawang merah di lahan pasang surut Sumatera Selatan. Buletin Teknik Pertanian, 12(1), 1-3.

Lehmann, J., da Silva Jr., J. P., Steiner, C., Nehls, T., Zech, W., \& Glaser, B. (2003). Nutrient availability and leaching in an archaeological Anthrosol and a Ferralsol of the Central Amazon basin: fertilizer, manure and charcoal amendments. Plant and Soil, 249, 343-357. https://doi.org/10.1023/A:1022833116184

Lehmann, J., \& Rondon, M. (2006). Bio-Char Soil Management on Highly Weathered Soils in the Humid Tropics. In N. Uphoff, A. S. Ball, E. Fernandes, O. Husson, M. Laing, C. Palm, ... J. Thies (Eds.), Biological Approaches to Sustainable Soil Systems (pp. 517-529). Boca Raton, FL: Taylor \& Francis Group. https://doi.org/10.1201/9781420017113 .ch36

Ma'ruf, A. (2016). Respon Beberapa Kultivar Tanaman Pangan Terhadap Salinitas. Jurnal Penelitian Pertanian BERNAS, 12(3), 11-19. https://doi.org/10.7910/DVN/9LWHOU

Mahdy, A. M. (2011). Comparative effects of different soil amendments on amelioration of saline-sodic soils. Soil and Water Research, 6(4), 205-216. https://doi.org/10.17221/11/2011-SWR
Major, J., Rondon, M., Molina, D., Riha, S. J., \& Lehmann, J. (2010). Maize yield and nutrition during 4 years after biochar application to a Colombian savanna oxisol. Plant and Soil, 333(1), 117-128. https://doi.org/10.1007/s11104-0100327-0

Mayun, I. A. (2007). Effect of Straw Mulch and cow manure towards growth and Yield of Shallot at Coastal Area. Agritrop, 26(1), 33-40.

Mindari, W., Aini, N., Kusuma, Z., \& Syekhfani, S. (2014). Effects of humic acid-based cation buffer on chemical characteristics of saline soil and growth of maize. Journal of Degraded and Mining Lands Management, 2(1), 259-268. https://doi.org/10.15243/jdmlm.2014.02 1.259

Mukherjee, A., \& Zimmerman, A. R. (2013). Organic carbon and nutrient release from a range of laboratory-produced biochars and biochar-soil mixtures. Geoderma, 193-194, 122-130. https://doi.org/10.1016/j.geoderma.201 2.10.002

Mulyono. (2000). Aplikasi Berbagai Macam Sumber Kalsium dan Dosis Bahan Organik sebagai Pembenah Sifat Fisik Tanah Garaman. Universitas Gadjah Mada.

Munir, M. (1996). Tanah Tanah Utama Indonesia: Karakteristik, Klasifikasi, dan Pemanfaatannya. Jakarta, Indonesia: Dunia Pustaka Jaya.

Nasyirah, N., Kalsim, D., \& Saptomo, S. (2015). Analysis of The Rate of Saline Soil Leaching by Using Subsurface Drainage. Jurnal Keteknikan Pertanian, 3(2), 89-96. https://doi.org/10.19028/jtep.03.2.89-96

Nugroho, B., Mildaryani, W., \& Dewi, S. H. C. (2019). Organic shallot cultivation by using siam weed compost combined with biocontrol agent of avirulent Fusarium Oxysporum F.Sp. cepae. IOP Conference Series: Earth and Environmental Science, 379, 012005. https://doi.org/10.1088/17551315/379/1/012005

Nurida, N. L. (2014). Potensi Pemanfaatan Biochar untuk Rehabilitasi Lahan Kering di Indonesia. Jurnal Sumberdaya Lahan Edisi 
Khusus,

$57-68$

https://doi.org/10.2018/jsdl.v8i3.6503

Orman, Ş. (2012). Effects of elemental sulphur and farmyard manure applications to calcareous saline clay loam soil on growth and some nutrient concentrations of tomato plants. Journal of Food, Agriculture and Environment, 10(2), 720725.

https://doi.org/10.1234/4.2012.3087

Parida, A. K., \& Das, A. B. (2004). Effects of $\mathrm{NaCl}$ stress on nitrogen and phosphorous metabolism in a true mangrove Bruguiera parviflora grown under hydroponic culture. Journal of Plant Physiology, 161(8), 921-928.

https://doi.org/10.1016/j.jplph.2003.11.006

Permentan. (2011). Peraturan Menteri Pertanian Nomor 70/Permentan/SR.140/10/2011 Tentang Pupuk Organik, Pupuk Hayati dan Pembenah Tanah. Retrieved from http://perundangan.pertanian.go.id/ad min/file/Permentan-70-11.pdf

Purwaningrahayu, R. D., \& Taufiq, A. (2018). Pemulsaan dan Ameliorasi Tanah Salin untuk Pertumbuhan dan Hasil Kedelai. Jurnal Agronomi Indonesia (Indonesian Journal of Agronomy), 46(2), 182-188. https://doi.org/10.24831/jai.v46i2.16517

Putra, C. R., Wahyudi, I., \& Hasanah, U. (2015). Serapan N (Nitrogen) dan Produksi Bawang Merah (Allium ascallonicum L) Varietas Lembah Palu Akibat Pemberian Bokashi Titonia (Titonia diversifolia) Pada Entisol Guntarano. E-J. Agrotekbis, 3(4), 448-454.

Qadir, M., Ghafoor, A., \& Murtaza, G. (2001). Use of saline-sodic waters through phytoremediation of calcareous salinesodic soils. Agricultural Water Management, 50(3), 197-210. https://doi.org/10.1016/S03783774(01)00101-9

Rachman, A., Subiksa, I. G. M., Erfandi, D., \& Slavich, P. (2008). Dynamics of TsunamiAffected Soil Properties. In F. Agus \& G. Tinning (Eds.), International Workshop on Post Tsunami Soil Management (pp. 5164). Bogor: Indonesian Soil Research Institute.
Rahayu, R., Mujiyo, M., \& Arini, R. U. (2018). Land suitability evaluation of shallot (Allium ascalonicum L.) at production centres in Losari District, Brebes. Journal of Degraded and Mining Lands Management, 6(1), 1505-1511. https://doi.org/10.15243/jdmlm.2018.06 1.1505

Rajiman, Yudono, P., Sulistyaningsih, E., \& Hanudin, E. (2008). Pengaruh Pembenah Tanah Terhadap Sifat Fisika Tanah dan Hasil Bawang Merah Pada Lahan Pasir Pantai Bugel Kabupaten Kulon Progo. Argin, 12(1), 67-77. https://doi.org/10.20884/1.agrin.2008.1 2.1 .80

Saleh, I. (2010). Uji Viabilitas Bibit Bawang Merah Pada Cekaman Salinitas. Logika, 21(1), 6-10.

Sasongko, P. E., \& Warsito. (2003). Perilaku Garam Na (Sodium) Pada Beberapa Tinggi Kolom Tanah Salin dan Pemberian Amandemen. Jurnal Penelitian IImu-IImu Pertanian, 3(1), 51-55.

Sembiring, H., Gani, A., \& Iskandar, T. (2008). Implications of Salinity Research in Aceh for Indonesia Rice Growing. In F. Agus \& G. Tinning (Eds.), International Workshop on Post Tsunami Soil Managemen (pp. 97-108). Bogor: Indonesian Soil Research Institute.

Simanjuntak, A., Lahay, R. R., \& Purba, E. (2013). Respon Pertumbuhan dan Produksi Bawang Merah (Allium ascalonicum L.) Terhadap Pemberian Pupuk NPK dan Kompos Kulit Buah Kopi. Jurnal Agroekoteknologi, 1(3), 362-373. https://doi.org/10.32734/jaet.v1i3.2273

Soinne, H., Hovi, J., Tammeorg, P., \& Turtola, E. (2014). Effect of biochar on phosphorus sorption and clay soil aggregate stability. Geoderma, 219-220, 162-167. https://doi.org/10.1016/j.geoderma.201 3.12.022

Subowo, Y. B. (2015). Penambahan Pupuk Hayati Jamur sebagai Pendukung Pertumbuhan Tanaman Padi (Oryza sativa) pada Tanah Salin. Prosiding Seminar Nasional Masyarakat Biodiversitas Indonesia, 1(1), 150-154. https://doi.org/10.13057/psnmbi/m010126 
Tejada, M., Garcia, C., Gonzalez, J. L., \& Hernandez, M. T. (2006). Use of organic amendment as a strategy for saline soil remediation: Influence on the physical, chemical and biological properties of soil. Soil Biology and Biochemistry, 38(6), 1413-1421.

https://doi.org/10.1016/j.soilbio.2005.1 0.017

Thomas, S. C., Frye, S., Gale, N., Garmon, M., Launchbury, R., Machado, N., ... Winsborough, C. (2013). Biochar mitigates negative effects of salt additions on two herbaceous plant species. Journal of Environmental Management, 129, 62-68. https://doi.org/10.1016/j.jenvman.2013. 05.057

Vermeulen, D., \& Van Niekerk, A. (2017). Machine learning performance for predicting soil salinity using different combinations of geomorphometric covariates. Geoderma, 299, 1-12. https://doi.org/10.1016/j.geoderma.201
7.03.013

Wahyudi, I. (2013). Perubahan Tingkat Serapan Nitrogen, Fosfor dan Organik Pasar pada Entisol Poboya. Jurnal Agroland, 20(1), 14-20.

Widawati, S., \& Suliasih. (2017). The impact of Azotobacter inoculation on shallot plants (Allium cepa) and available phosphate in saline soil. Biodiversitas, 18(1), 86-94. https://doi.org/10.13057/biodiv/d180113 Wigati, E. S., Syukur, A., \& Bambang, D. K. (2016). Pengaruh Takaran Bahan Organik Dan Tingkat Kelengasan Tanah Terhadap Serapan Fosfor Oleh Kacang Tunggak Di Tanah Pasir Pantai. Jurnal IImu Tanah Dan Lingkungan, 6(1), 53-58.

Zaki, S. naz S. (2016). Effect of Compost and Nitrogen Fertilization on Yield and Nutrients Uptake of Rice Crop under Saline Soil. Modern Chemistry \& Applications, 4(2), 1000183. https://doi.org/10.4172/2329-

6798.1000183 